ELKOM, Vol.11, No.2, Desember 2018, pp. 29 - 42

p-ISSN : 1907-0012 (print)

e-ISSN : 2714-5417 (online)

http://ejurnal.stekom.ac.id/index.php/home

- page 29

\title{
SISTEM PAKAR PENANGANAN KERUSAKAN KOMPUTER DAN PERIPHERALNYA
}

\author{
Gufron Gufron ${ }^{1}$; Danang Danang ${ }^{2}$ \\ ${ }^{1}$ Progdi Sistem Komputer - Sekolah Tinggi Elektronika dan Komputer (STEKOM), \\ gufron@gmail.com \\ ${ }^{2}$ Progdi Teknik ELektro - Sekolah Tinggi Elektronika dan Komputer (STEKOM), \\ danang@stekom.ac.id \\ Jl. Majapahit 605, Semarang, telp/fax : (024) 6723456
}

\begin{tabular}{l}
\hline ARTICLE INFO \\
\hline Article history: \\
Received 19 November 2018 \\
Received in revised form 23 Nov 2018 \\
Accepted 25 Nov 2018 \\
Available online 13 Desember 2018
\end{tabular}

\section{ABSTRACT}

In operating a computer, of course, often experience problems with the Windows operating system, such as a slow computer when reading data, missing icons on the desktop, application system crashes or files that can not be run, or error messages appear that are not understood, problems that arise this is not uncommon fatal so that it interferes with the work or activity that is being done. One of the right solutions to the above problem is by applying an object-oriented design that follows the Hierarchy rules (tree rules), which is that each stage will bring up several new stages and Forward Reasoning inference techniques with Dept First Search data search techniques, with the forward reasoning system the system will provide information for the problems encountered. The test results show the solution to the problem of any computer damage problem can help computer users to recognize and deal with computer damage.

Keywords: Expert System, Knowledge Base, Forward Reasoning, First Search Dept.

\section{Pendahuluan}

Pada umumnya pengguna komputer PC (Personal Komputer) menggunakan Sistem Operasi Windows. Dalam mengoperasikan komputer tentu sering mengalami masalah dengan sistem operasi Windows, seperti komputer lambat ketika membaca data, icon-icon yang hilang di dekstop, sistem crash aplikasi atau file yang tidak dapat dijalankan, ataupun muncul pesan kesalahan yang tidak dimengerti, masalah-masalah yang muncul ini tidak jarang berakibat fatal sehingga mengganggu pekerjaan atau aktifitas yang sedang dilakukan.

CV. Destinasi Computindo sebagai salah satu perusahaan konsultan yang bergerak dibidang penyedia barang dan jasa dan beralamat di Jl. Kedungmundu Raya Kampoeng Semawis Blok A 6/7 menangani 6 instansi Dinas Kependudukan dan Pencatatan Sipil kabupaten dan kota di jawa tengah antara lain Kab. Kendal, Kab. Jepara, Kab. Purworejo, Kab Blora, Kota Tegal, dan Kota Semarang, selalu ingin mengikuti perkembangan teknologi komputer yang sedang berkembang. Didirikan pada tanggal Tiga Belas Bulan April Tahun Duaribu Empat (13-4-2004). Tujuan usahanya adalah memberikan pelayanan jasa dibidang pengembangan Sistem Aplikasi khususnya Manajemen Database serta memberikan Jasa Konsultasi, Penyediaan Perangkat Keras dan Perangkat Lunak.

Pada awalnya jenis komputer yang ditangani oleh CV. Destinasi Computindo masih ber pentium 3 kebawah, karena berjalannya waktu dan perkembangan komputer yang begitu pesat kini mereka menangani

Received Nov 19, 2018; Revised Nov 23, 2018; Accepted Nov 25, 2018 
jenis komputer Pentium 4 diantaranya jenis motherboard Pentium 4 dengan tipe socket 478 mPGA dan socket 775 LGA.

Mekanisme perbaikan dimulai dari adanya sebuah laporan kerusakan dari pihak klien dalam hal ini adalah staf operator kepada seorang admin komputer yang kemudian diteruskan ke pihak teknisi CV. Destinasi Computindo.

Beberapa permasalahan yang sering muncul antara lain lambatnya penanganan perbaikan komputer dikarenakan jarak yang harus ditempuh untuk menuju ke tempat klien cukup jauh, yang terkadang hanya ditemukan kerusakan yang sederhana, sehingga kurang efisien.

Begitu juga dalam menentukan sebuah kerusakan, terkadang seorang teknisi atau admin membuat kesalahan dalam menentukan komponen yang rusak, yang berakibat kesalahan dalam menyediakan sparepart sehingga tidak efisien. Dikarenakan dalam proses menentukan kerusakan, seorang teknisi belum memiliki sarana atau alat bantu yang dapat membantu melacak sebuah kerusakan.

Jika terjadi kesalahan dalam menentukan sebuah komponen yang rusak, bukan tidak mungkin akan memunculkan permasalahan baru. Begitu juga dengan perbaikan di tempat client. Terkadang jika kerusakan terlalu kompleks dan tidak dapat diperbaiki di tempat, maka harus dibawa oleh seorang teknisi yang tentunya akan menambah resiko.

Selain itu seorang teknisi baru juga tidak dapat menguji kemampuannya setiap saat dikarenakan tidak setiap hari terdapat komputer yang rusak untuk dipelajari. Sehingga sangat diharapkan memiliki sebuah aplikasi yang dapat membantu seorang teknisi dalam menentukan sebuah kerusakan pada PC. Sehingga akan mengurangi resiko dan pengeluaran biaya yang tidak diperlukan. Dan tentunya akan menguntungkan bagi CV. Destinasi Computindo secara keuangan.

\section{Landasan Teori}

Beberapa metodologi pengembangan sistem yang terstruktur telah diperkenalkan secara luas. Metodologi pengembangan sistem adalah kesatuan metode-metode, prosedur-prosedur, konsep-konsep pekerjaan, aturan-aturan dan postulat-postulat yang digunakan dalam mengembangkan suatu sistem informasi. Sedangkan metode adalah suatu cara, teknik yang sistematik untuk mengerjakan sesuatu. Sebagian besar metodologi diperuntukan bagi tahap desain saja, namun banyak juga yang dapat digunakan untuk tahap analisis. Metodologi yang dibahas berikut ini dapat digunakan pada tahap analisis dan disain dan menggunakan pendekatan pengembangan sistem terstruktur

Sistem pakar setidak - tidaknya mempunyai dua unsur manusia atau lebih yang terlibat di dalam pembangunan dan pengembangan serta penggunaannya. Minimal, ada seseorang yang pembangun dan ada penggunanya. Sering juga ada pakar dan perekayasa pengetahuan (knowledge engineer). Menurut Turba (2001), ada 4 unsur manusia dalam sistem pakar

Komputer adalah alat yang dipakai untuk mengolah data menurut prosedur yang telah dirumuskan. Kata komputer pertama dipergunakan untuk menggambarkan orang yang pekerjaannya melakukan perhitungan aritmatika dengan atau tanpa alat bantu, tetapi arti kata ini kemudian dipindahkan kepada mesin itu sendiri. Asal mulanya, pengolahan informasi hampir eksklusif berhubungan dengan masalah aritmatika, tetapi komputer modern dipakai untuk banyak tugas yang tidak berhubungan dengan matematika. (Lim Rusyamsi, 2009).

Microsoft Access (Microsoft Office Access) adalah sebuah program aplikasi basis data komputer relasional yang ditujukan untuk kalangan rumahan dan perusahaan kecil hingga menengah, dan juga menggunakan tampilan grafis yang intuitif sehingga memudahkan pengguna. Versi terakhir adalah Microsoft Office Access 2007 yang termasuk ke dalam Microsoft Office System 2007. (Andi, 2009)

Peripheral adalah hardware tambahan yang disambungkan ke komputer, biasanya dengan bantuan kabel. Atau dengan kata lain peralatan pendukung dari sebuah PC. Peripheral ini bertugas membantu komputer menyelesaikan tugas yang tidak dapat dilakukan oleh hardware yang sudah terpasang didalam casing. (Ahmad Yani, 2008)

SISTEM PAKAR PENANGANAN KERUSAKAN KOMPUTER DAN PERIPHERALNYA (Gufron) 


\section{Metodologi}

Metodologi merupakan kerangka teoritis yang dipergunakan oleh penulis untuk menganalisa, mengerjakan atau mengatasi masalah yang dihadapi.

\section{Metode Pengumpulan Data}

Metode yang digunakan penulis dalam penyusunan proposal ini adalah dengan menggunakan metode pengumpulan data sebagai berikut:

a. Wawancara (Interview)

b. Penulis mengadakan tanya jawab langsung dengan kepala teknisi CV. Destinasi Computindo mengenai permasalahan - permasalahan yang dihadapi perusahaan, latar belakang perusahaan dan lain - lain

c. Pengamatan (Observasi)

d. Penulis mengamati secara langsung bagaimanana cara-cara yang dilakukan oleh para teknisi komputer dalam menangani kerusakan-kerusakan perangkat komputer.

e. Studi Pustaka

f. Penulis melakukan pengumpulan data dengan mengupayakan buku-buku literatur yang berhubungan dengan teknologi perangkat komputer dan buku-buku pemrograman komputer yang mendukung dalam pembuatan sistem pakar.

2. Metode Pengembangan Sistem

SDLC ( Sistem Development Life Cycle )

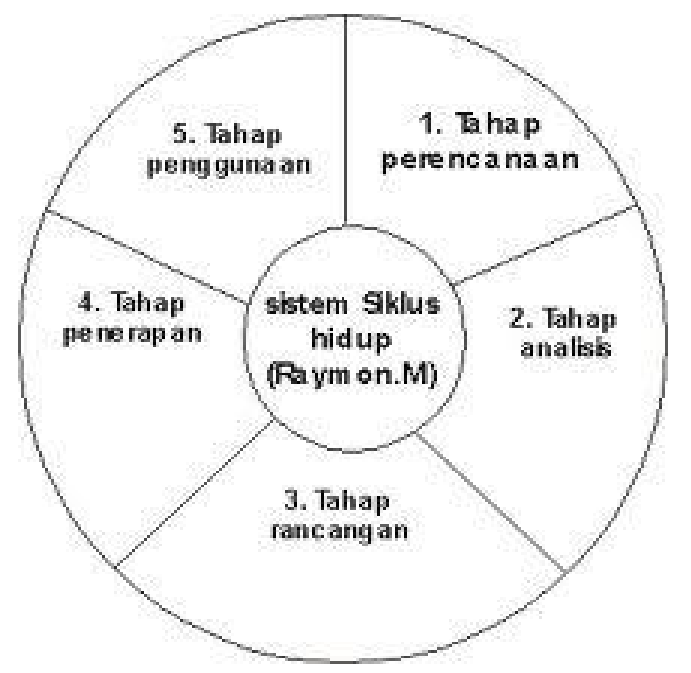

Gambar 1 Siklus Hidup Sistem (Raymond McLeod, 2010)

Dalam penelitian ini menggunakan metode pendekatan System Development Life Cycle ( SDLC ). Metode ini meliputi :

\section{a. Tahap Perencanaan}

1) Menyadari masalah yang ada di CV. Destinasi Computindo yaitu tentang mekanisme maintenance komputer.

2) Mengetahui alur proses kegiatan maintenance di CV. Destinasi Computindo dari laporan telpon masuk, penerimaan laporan, penyusunan jadwal, sampai penanganan perbaikan.

ELKOM Vol. 11, No. 2, Desember 2018 : $29-42$ 
3) Menentukan tujuan sistem agar sesuai dengan misi CV. Destinasi Computindo sebagai perusahaan konsultan yang bergerak di bidang tehnologi informasi.

4) Mengidentifikasi kendala-kendala dalam proses perbaikan komputer dan mempelajari permasalahan dalam proses penanganan kerusakan komputer di CV. Destinasi Computindo.

\section{b. Tahap Analisis}

1) Mengumpulkan data-data klien yang ditangani CV. Destinasi Computindo dengan melakukan wawancara kepada kepala teknisi CV. Destinasi Computindo dan melakukan pengamatan serta survey tentang proses perbaikan komputer dilapangan.

2) Mendefinisikan kriteria kinerja sistem dengan mempelajari struktur organisasi di CV. Destinasi Computindo.

3) Menyiapkan usulan rancangan sistem yang sesuai dengan permasalahan yang menjadi kendala dalam proses perbaikan komputer di CV. Destinasi Computindo.

\section{c. Tahap Perancangan}

1) Membuat rancangan terstruktur diantaranya DFD, ERD, Database, Normalisasi dan rancangan Input / Output.

2) Mempelajari dan menggambarkan logika perangkat lunak visual basic dalam proses pembuatan sistem pakar.

3) Membuat rancangan database dengan Microsoft Access XP

\section{d. Tahap Penerapan Sistem}

1) Merencanakan metode penerapan tentang sistem yang akan dipasang.

2) Mendapatkan sumberdaya perangkat keras, seperti komputer sesuai spesifikasi yang diperlukan.

3) Mendapatkan sumberdaya perangkat lunak seperti OS Windows XP dan Microsoft Access.

4) Menyiapkan database yang akan digunakan sebagai bank data sistem pakar.

5) Mendidik para teknisi CV. Destinasi Computindo sebagai user / pemakai untuk menggunakan dan masuk ke sistem baru.

6) Mengimplementasikan program aplikasi sistem pakar di lingkungan CV. Destinasi Computindo.

\section{e. Tahap Penggunaan Sistem}

1) Menggunakan program aplikasi sistem pakar di lingkungan CV. Destinasi Computindo.

2) Melakukan audit dan evaluasi sistem.

3) Memelihara program aplikasi sistem pakar (modifikasi sistem) sesuai perkembangan teknologi.

4) Melakukan perawatan sistem dan update database oleh admin di kantor CV. Destinasi Computindo.

\section{A. Konseptualisasi}

Identifikasi kerusakan pada hardware komputer memang sangat membutuhkan pengalaman dan pengetahuan yang cermat mengenai ciri-ciri kerusakan serta gejala-gejala kerusakan dan sebab-sebab utama kerusakan yang dimiliki oleh komputer tersebut. Sebab banyak sekali gejala-gejala kerusakan yang hampir sama apabila kita tidak jeli dan teliti dalam menelusurinya. Dari hasil tersebut diatas diperoleh suatu konsep mengembangkannya sistem pakar ini yaitu identifikasi jenis kerusakan pada hardware komputer dan bagaimana caranya untuk menanggulangi atau menentukan solusi dari kerusakan tersebut. Dimana dapat dilakukan dengan memperhatikan bagian-bagian pada komputer yang tampak jelas dan yang membedakan antara lain ciri-ciri dari gejala yang timbul pada bagian kerusakan tersebut.

Dalam tahapan konseptualisasi merupakan tahap dimana knowledge engineer dan pakar menentukan konsep yang akan dikembangkan menjadi sistem pakar yang baik dan mudah untuk dapat dipergunakan nantinya. Dari seluruh konsep dikaji dan dirinci unsur-unsur yang terlibat serta menentukan hubungan dan mekanisme pengendalian yang diperlukan untuk mencapai solusi. 
B. Flow of Dokument Perbaikan Komputer

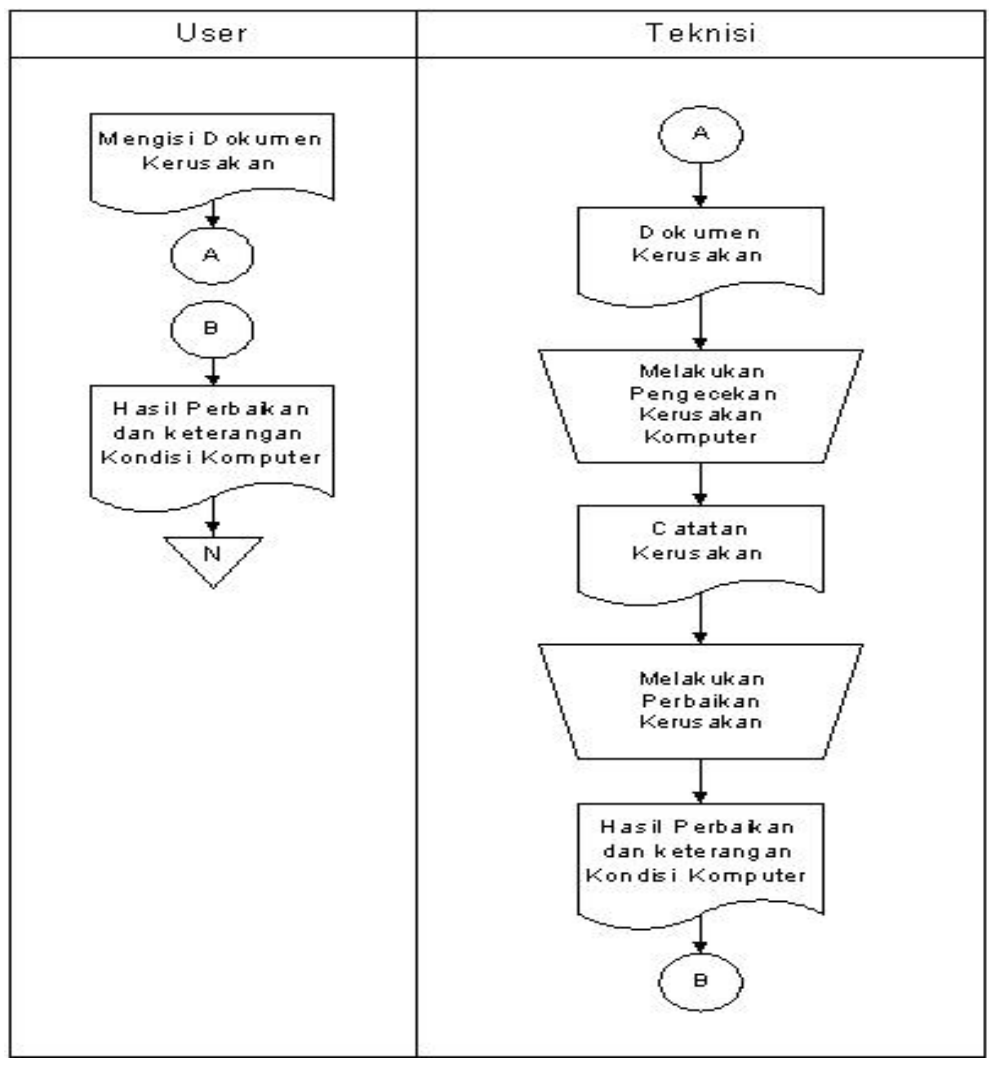

Gambar 2 Flow of Dokument Perbaikan Komputer

\section{Narasi Sistem Lama}

Alur proses perbaikan di CV. Destinasi Computindo

1. User mengisi dokumen kerusakan yang selanjutnya diserahkan kepada teknisi untuk didokumentasikan.

2. Seorang teknisi selanjutnya melakukan pengecekan kerusakan komputer dan mencatat jenis kerusakannya.

3. Setelah mengetahui bagian yang rusak selanjutnya seorang teknisi melakukan perbaikan kerusakan dan mendokumentasikan hasil perbaikan komputer.

4. Hasil perbaikan dan keterangan kondisi komputer selanjutnya dilaporkan kepada user.

\section{DFD (Data Flow Diagram)}

Perancangan dari sistem informasi secara fisik akan digambarkan dalam bentuk Data Flow Diagram (DFD). Data Flow Diagram (DFD) adalah alat yang digunakan pada metodologi pengembangan sistem yang terstruktur dan sebagai sarana untuk mendokumentasikan sistem yang baik. Data Flow Diagram (DFD) digambarkan mulai dari keseluruhan sistem dengan satu proses dan menggambarkan sumber dari tujuan data secara jelas, kemudian diperinci proses-proses yang ada di dalam fungsinya masing-masing. Context Diagram merupakan langkah awal dari analisa terstruktur dan merupakan gambaran dari suatu sistem. Diagram ini digunakan untuk memperlihatkan ruang lingkup atau batasan dari sistem. Adapun Context Diagram yang ada pada Sistem Pakar adalah sebagai berikut :

ELKOM Vol. 11, No. 2, Desember 2018: $29-42$ 
1. Diagram Context

Diagram konteks adalah alur data yang berfungsi untuk menggambarkan keterkaitan aliranaliran data antara sistem dengan bagian-bagian luar. Adapun diagram konteks untuk sistem yang akan dibangun dapat dilihat pada gambar 4.1
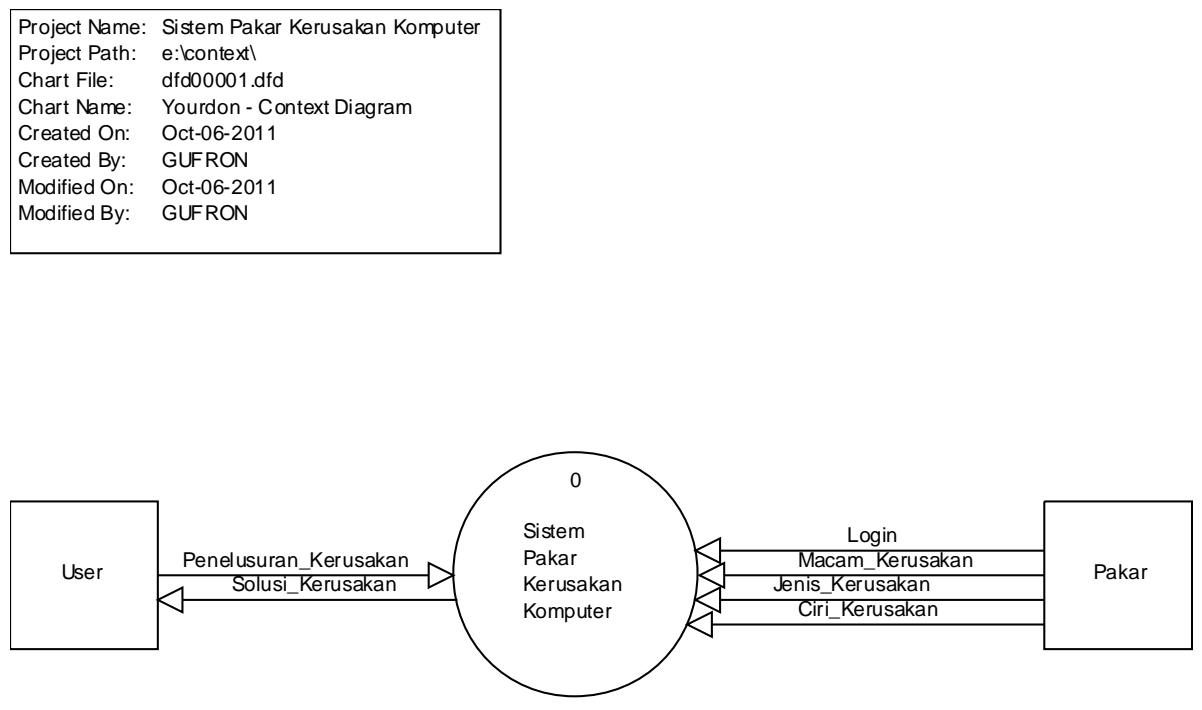

\section{Gambar 3 Diagram Context}

\section{Normalisasi}

Normalisasi merupakan proses pengelompokan data elemen menjadi tabel - tabel yang menunjukkan entitas relasinya. Pada proses normalisasi selalu diuji pada beberapa kondisi, apakah ada kesulitan pada saat menambah, menghapus, mengubah ataupun membaca pada suatu database.

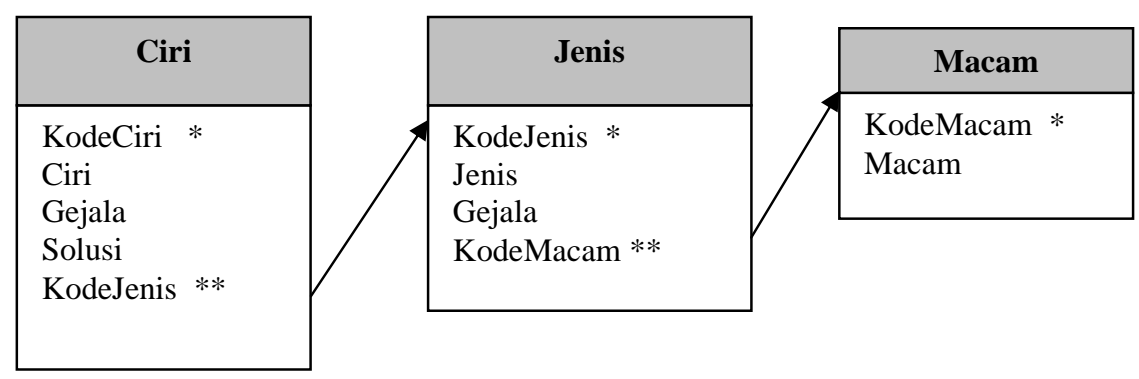

Gambar 4 Bentuk Normal Ke-Dua ( 2NF )

\section{ERD ( Entity Relationship Diagram )}

Entity Relationship Diagram adalah konsep yang mendeskripsikan hubungan penyimpanan tabel dalam DFD. ERD digunakan untuk memudahkan pengertian hubungan antara satu file dengan file lainnya. 


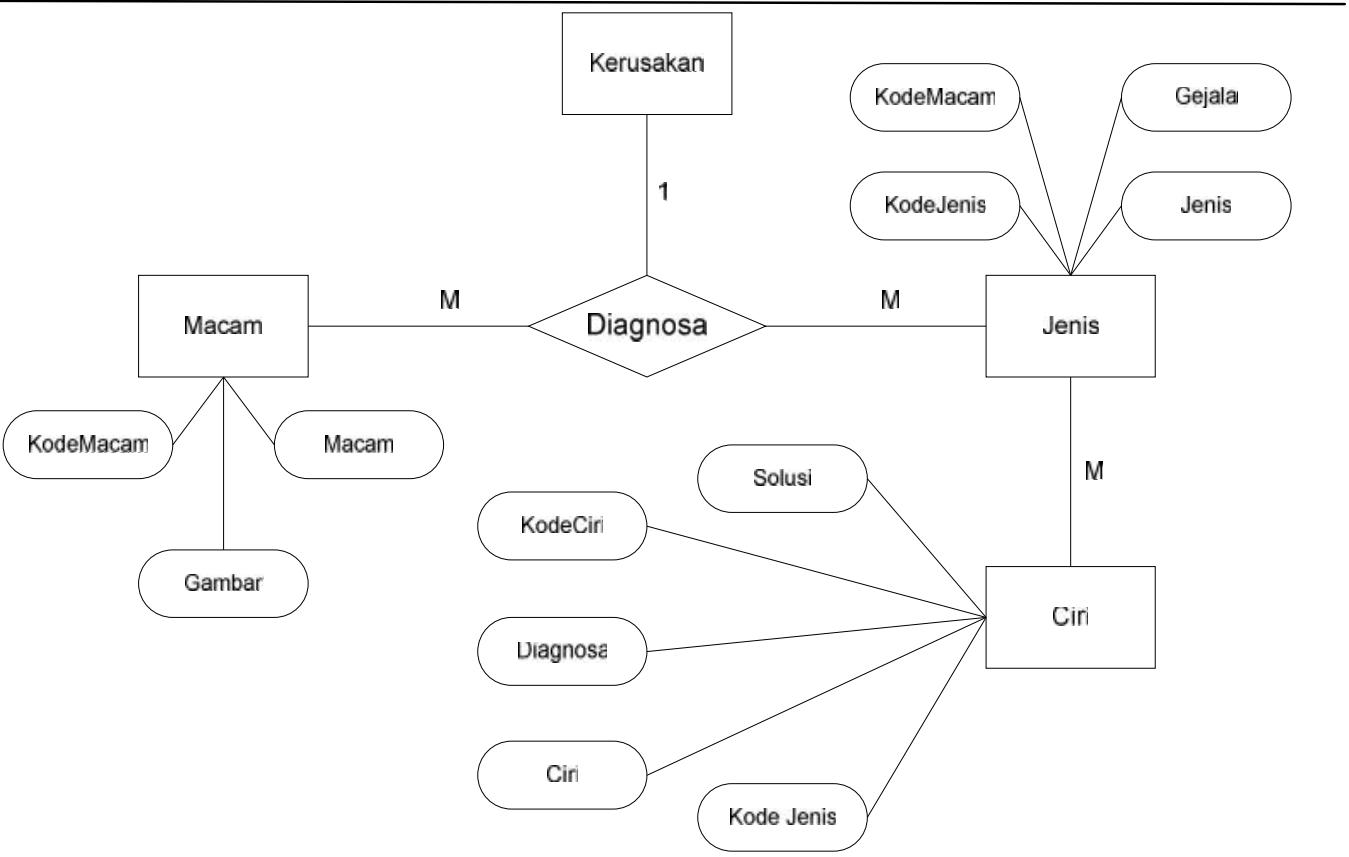

Gambar 5 ERD ( Entity Relationship Diagram )

\section{Hasil dan Pembahasan}

a. Desain Form Login Sistem untuk User

\section{Password}

\section{Pilihan Anda}

- Pemakai

C Pakar

Nama

Password

\section{Login}

Keluar

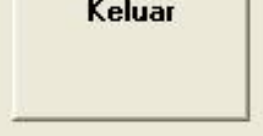

Ubah Password

\section{Gambar 6 Form Login User}

Keterangan :

User biasa atau pemakai, untuk masuk ke dalam aplikasi sistem pakar ini tidak perlu memasukkan password. Jadi langsung klik Login untuk mengakses aplikasi sistem pakar tersebut.

ELKOM Vol. 11, No. 2, Desember 2018: $29-42$ 
37

b. Desain Tampilan Menu untuk Pemakai

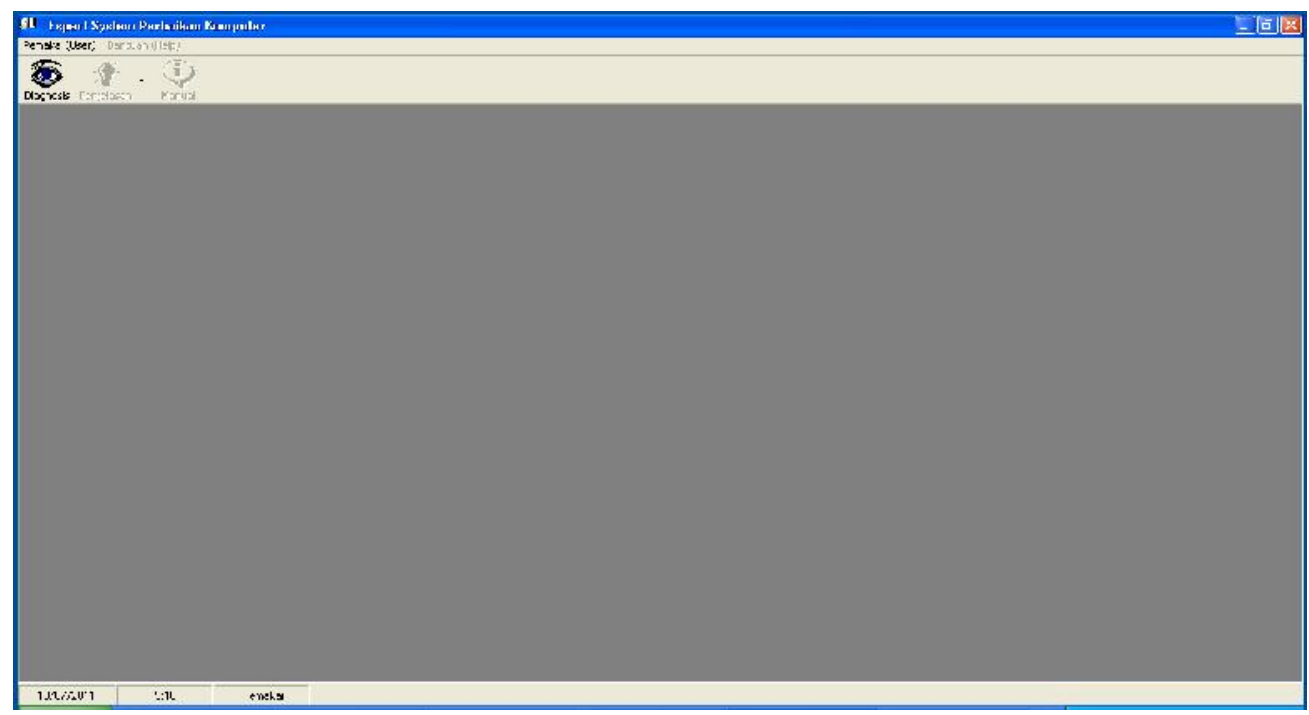

Gambar 7 Form Tampilan Menu untuk Pemakai

Keterangan :

User biasa atau pemakai hanya dapat mengakses menu Diagnosa yang isinya Penelusuran Kerusakan.

c. Desain Tampilan Form Penelusuran Macam Kerusakan

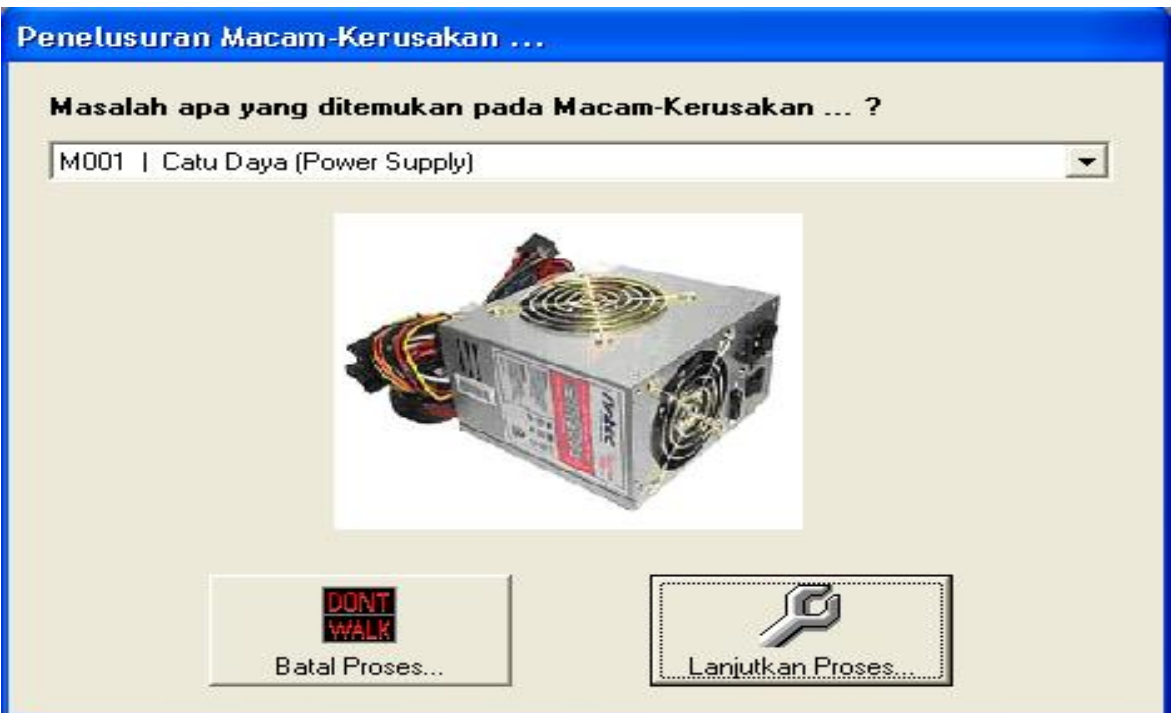

Keterangan :

\section{Gambar 8 Form Penelusuran Macam Kerusakan}

Dalam Form Penelusuran Macam Kerusakan, user dapat memilih Macam kerusakan sesuai dengan kerusakan yang user alami. Kemudian klik tombol Lanjutkan Proses untuk melanjutkan proses selanjutnya yaitu pencarian Jenis Kerusakan. 
d. Desain Tampilan Form Penelusuran Jenis Kerusakan

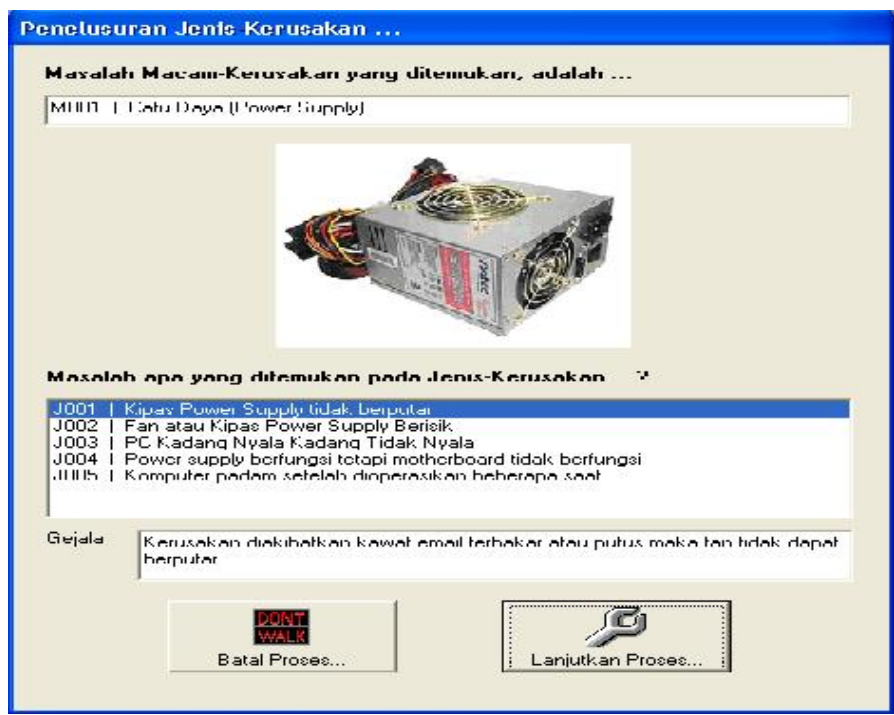

Gambar 9 Form Penelusuran Jenis Kerusakan

Keterangan :

Form Penelusuran Jenis Kerusakan merupakan kelanjutan penelusuran kerusakan berdasarkan Macam kerusakan yang di pilih sebelumnya. User dapat memilih masalah apa yang ditemukan pada Jenis Kerusakan yang dialami oleh user tersebut, sehingga nanti akan di tampilkan Gejala Kerusakan sesuai dengan apa yang dialami oleh user. Klik tombol Lanjutkan Proses untuk melanjutkan proses berikutnya yaitu Ciri Kerusakan.

e. Desain Tampilan Form Penelusuran Ciri Kerusakan

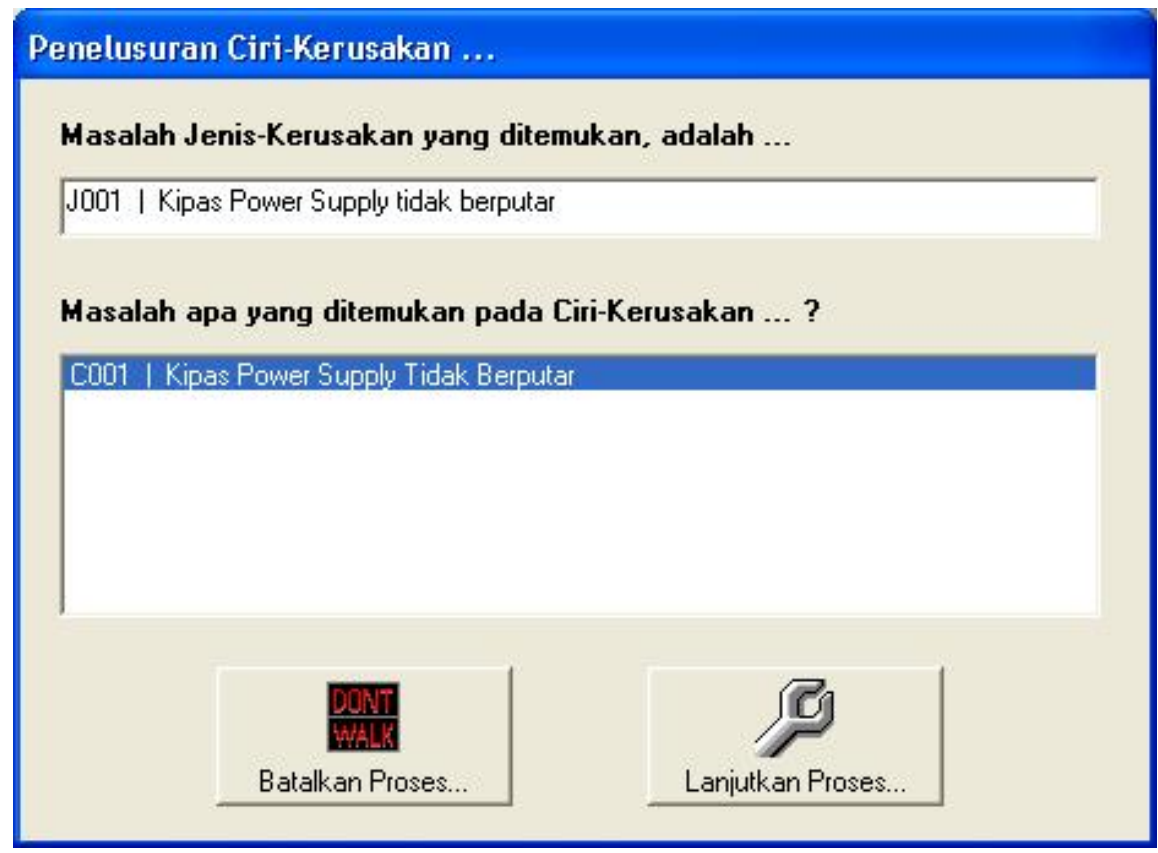

Gambar 10 Form Penelusuran Ciri Kerusakan

ELKOM Vol. 11, No. 2, Desember 2018: 29-42 
Keterangan :

Dari masalah kerusakan yang sebelumnya user pilih, aplikasi akan menampilkan ciri - ciri kerusakan berdasarkan jenis yang user pilih. Klik Lanjutkan Proses untuk melanjutkan proses berikutnya.

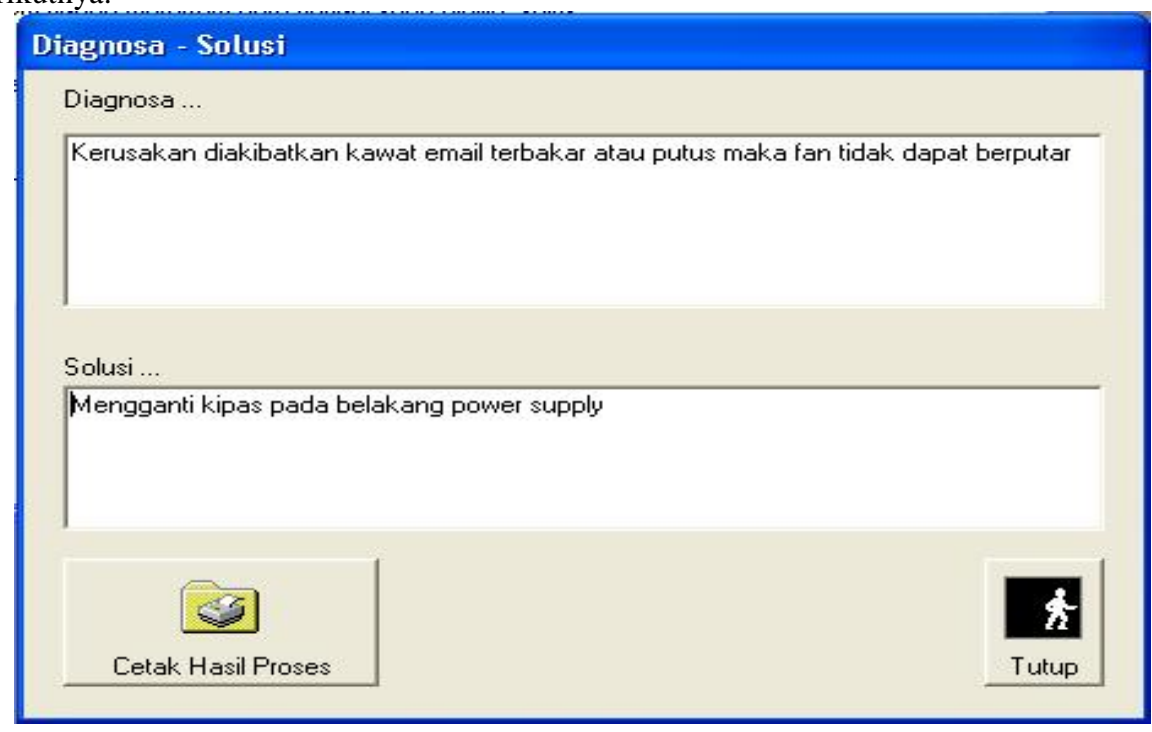

\section{Gambar 11 Form Diagnosa, dan Solusi}

Keterangan :

Form ini merupakan informasi yang dihasilkan berdasarkan gejala - gejala awal yang dialami user, diagnosa, serta solusi yang di berikan oleh sistem pakar tersebut. Tombol Cetak Hasil Proses digunakan untuk mencetak hasilnya dalam bentuk printout.

f. Desain Output Tampilan Hasil Diagnosa

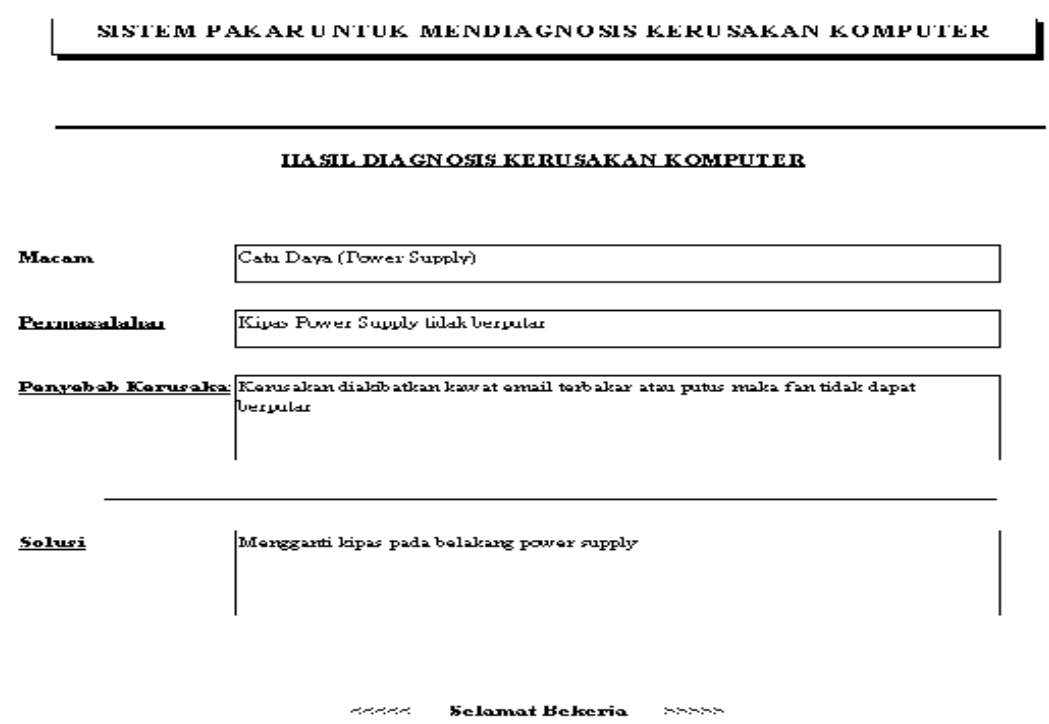

Gambar 12 Output Hasil Diagnosa

SISTEM PAKAR PENANGANAN KERUSAKAN KOMPUTER DAN PERIPHERALNYA (Gufron) 
g. Desain Tampilan Form Login

\section{Passurord}

Pilihan Anda

C Pemakai

- Pakar Nama pakar

Keluar

Password

$++++$

Login

Ubah Password

Gambar 13 Form Login untuk Pakar

Keterangan :

Pakar untuk mengakses aplikasi ini harus memasukkan nama dan password terlebih dahulu, dengan tujuan supaya data knowledge base yang diinputkan oleh Pakar tidak bisa di ganti sembarangan oleh siapapun.

h. Desain Form Menu Utama

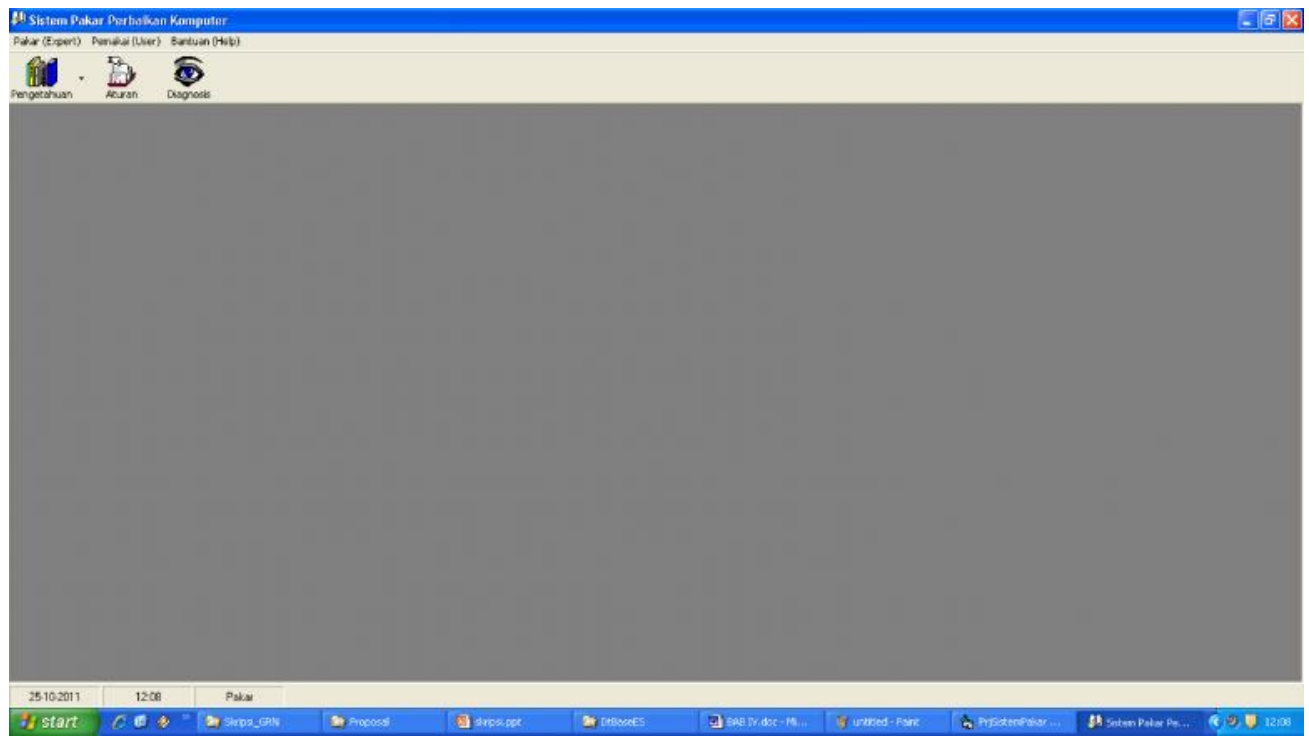

Gambar 14 Form Utama untuk Pakar

Keterangan :

User Pakar dapat mengakses menu Penelusuran dan Aturan yang isinya Penelusuran Kerusakan

ELKOM Vol. 11, No. 2, Desember 2018: $29-42$ 
i. Desain Tampilan Form Input Macam Kerusakan

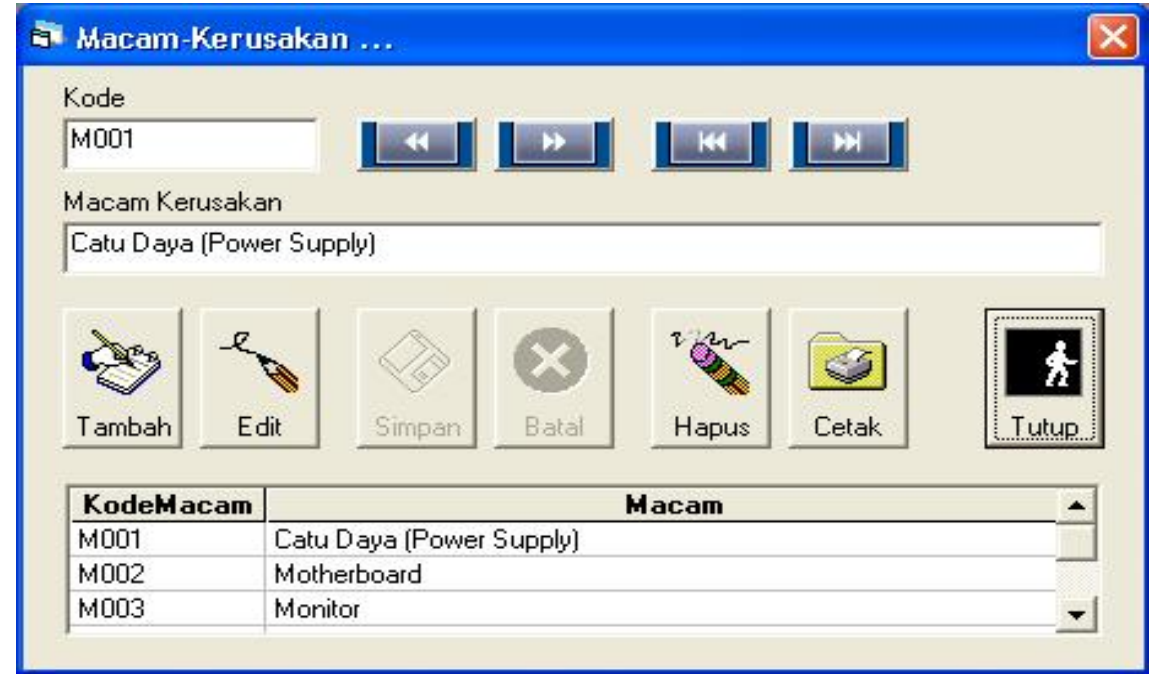

\section{Gambar 15 Form Input Macam Kerusakan}

Keterangan :

Dalam Form Macam Kerusakan, seorang pakar dapat menambah, mengedit, menghapus dan mencetak macam kerusakan sesuai dengan pengembangan perangkat komponen.

j. Desain Tampilan Form Input Basis Aturan Kepakaran

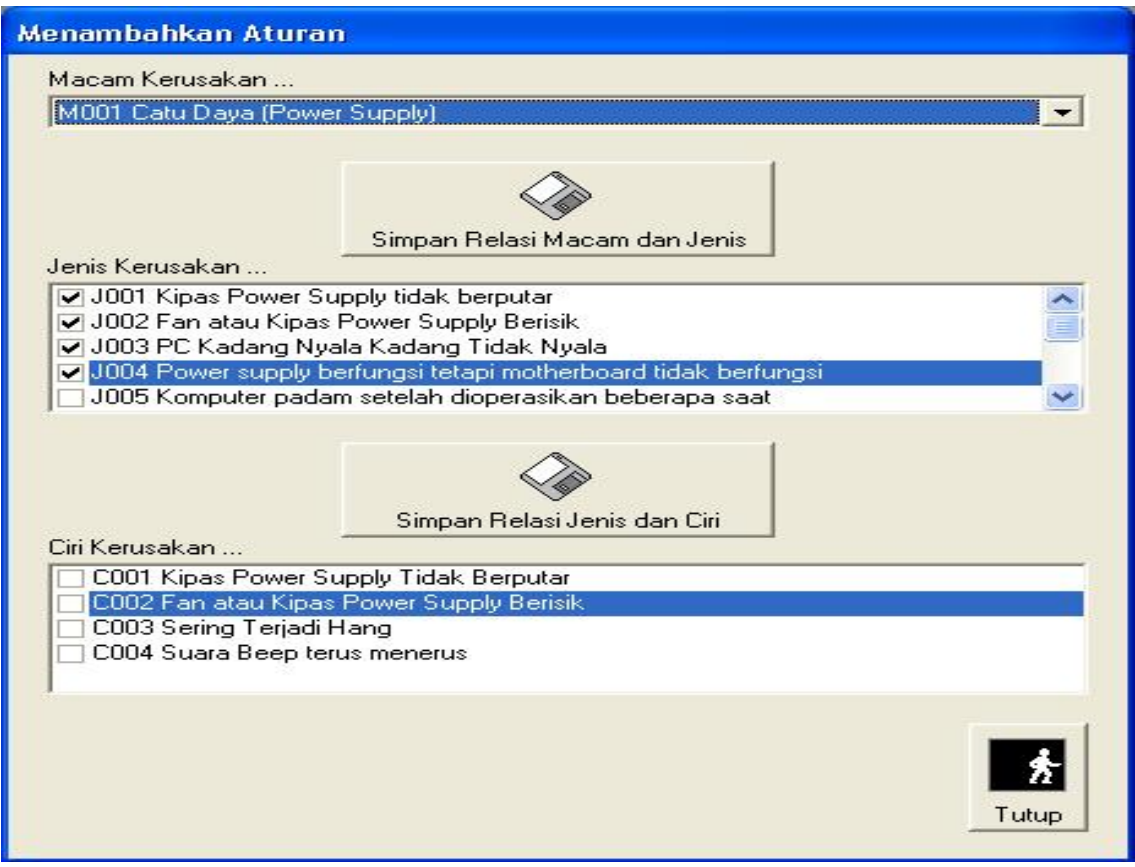

Gambar 16 Form Input Basis Aturan Kepakaran 
Keterangan :

Form Aturan digunakan untuk menghubungkan atau merelasikan data dari form macam kerusakan, form jenis kerusakan dan form ciri kerusakan. Yang hasilnya dapat dilihat pada saat melakukan penelusuran / diagnosa.

\section{Kesimpulan}

Dari hasil penelitian dan pengamatan yang telah dilakukan oleh penulis, maka penulis dapat mengambil kesimpulan sebagai berikut :

a. Dengan adanya Aplikasi Sistem Pakar Penanganan Kerusakan Komputer dan Peripheralnya, dapat membantu seorang teknisi dalam melakukan perbaikan sebuah komputer.

b. Para pengguna komputer dapat mencoba memperbaiki sendiri kerusakan-kerusakan yang terjadi pada komputer serta dapat menghemat biaya yang dikeluarkan untuk ke service komputer dengan menggunakan sistem pakar ini.

c. Tujuan utama dari Sistem Pakar Penanganan Kerusakan Komputer dan Peripheralnya adalah membantu staff IT dari CV. Destinasi Computindo dalam menangani kerusakan komputer. Selain dari tujuan utama tersebut, sistem pakar ini juga dapat memberikan pengetahuan dan informasi penting yang berkaitan dengan perangkat komputer.

\section{Daftar Pustaka}

Alam, Agus, 2007; “Manajemen Database dengan Microsoft Visual Basic6.0”, Yogyakarta: Penerbit Graha Ilmu.

Andi, 2009; "Pengembangan Sistem Pakar Menggunakan Visual Basic”, Yogyakarta: CV. Andi Offset.

Arhami, Muhammad, 2007; “Konsep Dasar Sistem Pakar”, Yogyakarta: Andi Offset.

Giarratano, Riley, 2005; “Artificial Intellegense”, Andi, YogyakartaIndayudha, Fery, 2008; “Jago Merakit dan Memperbaiki Komputer”, Yogyakarta: Andi Offset.

Kristanto, Andri, 2008; “Kecerdasan Buatan”, Yogyakarta: PenerbitGraha Ilmu.Haryanto, Kristanto, 2005; "Normalisasi”, Andi, Yogyakarta

Kristanto, Haryanto, 2007; “Konsep dan Perancangan Database”, Yogyakarta: Andi Offset.

McLeod, Raymond, Jr. dan P. Schell, George, 2010; “Sistem InformasiManajemen”, Edisi kesembilan, Jakarta: PT. Indeks

Rusmawan, Uus, 2007; “Konsep dan Implementasi Visual Basic 6.0”,Jakarta: PT. Elex Media Komputindo.

Rusyamsi, Lim, 2009; “Menjadi Dokter Specialis Komputer”, Jakarta penerbit: PT. Kawan Pustaka

Simba, Patria, Yan, 2010; “Trik Mengatasi Masalah Komputer sehari-hari

Untuk pemula”, Jakarta: PT. Elex Media Komputindo

Yani, Ahmad, 2008; “Panduan menjadi teknisi komputer”, Jakarta: AndiOffset.

Yuswanto, 2007; “Pemrograman Dasar Visual Basic 6.0”, Solo: CV.Aneka.

W.JS. Purwadarminta, 2010; "Kamus Umum Bahasa Indonesia”, Jakarta : Balai Pustaka

ELKOM Vol. 11, No. 2, Desember 2018: $29-42$ 